\title{
Turkish Adaptation of Parents' Gendered Emotion Beliefs Scale: Validity and Reliability Study of Turkish Parents
}

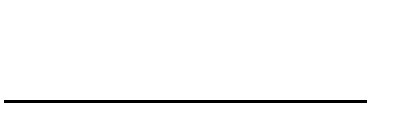

Article History:

Received 16.12.2020

revised form 21.10.2021

Available online

01.01.2022

\author{
Siğnem BAĞCI ${ }^{1}$, Serdal SEVEN ${ }^{2}$
}

The purpose of this study is to analyze the validity and reliability of the Parents' Gendered Emotion Beliefs Scale developed by Thomassin et al. (2019) for the adaptation of the Turkish version for Turkish Parents. The study was conducted on a total of 136 parents, including 69 mothers and 67 fathers, with 36-72 monthold-children in Istanbul province, Bahçelievler district. The obtained data were analyzed using descriptive analysis. In order to examine the validity and reliability of the scale, Kaiser-Meyer-Olkin (KMO), Bartlett Test, Confirmatory Factor Analysis, Exploratory Factor Analysis methods, as well as Comparative Fit Index (CFI), Tucker Lewis Index (TLI), Cronbach's alpha internal consistency coefficient and independent samples T-test were used. As a result of the study, it was found that the Turkish adaptation of the Parents' Gendered Emotion Beliefs Scale adapted to Turkish is sufficiently valid and reliable.

(C) IJERE. All rights reserved

Keywords: Parents, gender, emotion, beliefs, scale adaptation, preschool period.

\section{INTRODUCTION}

It is widely acknowledged that parents are one of the most important factors in the development of children's emotional skills in the emotional socialization process (Eisenberg et al., 1998; Zeman et al., 2010). Moreover, many studies have proved that some parental emotion socialization practices can facilitate children's emotional development by supporting them (Denham et al., 2007), while other practices may prevent the development of children's adaptable emotional skills by making it difficult, thus causing harmful consequences (Denham et al., 1997). As supported by various studies, gender differences in children's emotional expressions and emotional socialization are quite evident. This proves that gender is an important factor in the socialization process (Chaplin \& Aldao, 2013; Chaplin et al., 2005). Research shows that emotion parenting practices vary according to the gender of both the parent and the child. This suggests that parents may adhere to socially approved gender roles (Chaplin et al. 2005).

These findings show that obtaining information by researching the beliefs that motivate parents' emotional socialization practices will be highly beneficial for understanding children's emotional development and correct emotional socialization practices. However, when the literature is reviewed, it is clear that gender-based findings with regard to emotional socialization arehighly complicated. Unfortunately, little is known about the role of gender in the emotional development of parental practices, and consequently, on children. Considering the studies conducted in Turkey, it is seen that there is currently no scale that can measure the emotional beliefs of preschool children by examining their parents, and these beliefs are not studied to the extent necessary.

The ability to measure parents' beliefs consistent with how the gender role affects the expression of emotions and feelings, which will be defined as "gender-based beliefs" in this study, will be important for the abovementioned reasons. In this context, the aim of this study is to examine the "Parents' Gendered Emotion Beliefs (PGEB)" scale developed by Thomassin, K., Seddon, JA, and Vaughn-Coaxum, R. (2019) for Turkish parents with 36-72 months old children in preschool education, to conduct validity and reliability analyses and to adapt it to Turkish parents in order to eliminate the deficiency in the literature.

\section{Gender Factor in Emotional Socialization Process}

Children's attitudes and behaviors towards gender are influenced by their parents' attitudes towards gender and their support for gender-based behaviors (Lytton and Romney, 1991; Tenenbaum and Leaper, 2002). Parents socialize their children's emotions within the limits of "femininity" and "masculinity" norms, which are also shaped by the culture in which they live (Brody, 2000; Root \& Denham, 2010). For example, in some cultures, male children are discouraged to show expressions of sadness and crying and those that do are

${ }^{1}$ Milli Eğitim Bakanlığı, bagcisignem@gmail.com, orcid.org/0000-0002-9696-3930

${ }^{2}$ Fatih Sultan Mehmet Vakıf Üniversitesi, sseven@fsm.edu.tr, orcid.org/0000-0003-3965-4725 
perceived negatively, whereas expressions of anger and aggression are perceived to be acceptable and positive. In girls, on the other hand, aggression can be evaluated negatively (Crick, 1997; Serbin et al., 1993).

When the emotional socialization process of the parents was considered, it was observed that fathers showed more anger expressions towards their sons, while mothers approached their daughters with more positive emotions. The fact that fathers act as models by showing positive emotions to both girls and boys while playing the role of playmates also supports the mother in the process of being a model (Garner et al., 1997). While parents are coaching emotions, they are socialized by associating girls with expressions of emotion and interpersonal relations, and boys with autonomy (Block, 1983). It is emphasized that the guidance provided by mothers by talking with their children about emotions causes emotional sensitivity in interpersonal relationships in girls, and helps boys to gain an emotional problem-solving approach (Fivush, 1989). Studies have presented supportive results for these findings, and it has been observed that preschool parents use emotion words more frequently in emotional conversations involving sadness with girls than boys (Adams et al., 1995; Fivush, 1991; Fivush et al., 2000; Kuebli \& Fivush, 1992). Other studies with school-age girls have also shown that fathers talk more about their sadness with girls and pay more attention to girls expressing their sadness (Zeman et al., 2010; Chaplin et al., 2005).

One of the common findings of studies conducted with different research techniques such as observations and scales is that girls respond to emotional states with fear and sadness, while boys show feelings of anger and anger with more positive, supportive and encouraging reactions (Brody, 1997; Cassano et al., 2007; KlimesDougan et al., 2007). These studies show that the parental emotional socialization process supports girls' emotional sensitivity and emotional expression skills, and enables boys to better control their emotions (Brody, 2000; Fivush, 1989; Jansz, 2000). It should not be forgotten that in these studies, mostly middle and middleupper socioeconomic level families and their children are created and socioeconomic level is an important factor in emotional socialization and gender studies (O'Neal and Magai, 2005).

\section{METHOD}

\section{Participants}

The sample of this scale adaptation study consisted of 136 parents with 36-72-month-old children who were attending pre-school education in the fall semester of the 2020-2021 academic year in the Bahçelievler district of Istanbul. From the total of 136 parents participating in the study, 69 were mothers and 67 were fathers. The majority of the parents $(\mathrm{N}=63)$ were between 31 and 37 years old. The participants were distributed in the following age groups: $38-44(\mathrm{~N}=38), 24-30(\mathrm{~N}=26), 44-50(\mathrm{~N}=8)$ and 50 and over $(\mathrm{N}=1)$. Based on the information received from the participants about their children, it was determined that 68 of the children were girls and 68 were boys. The majority of the children were between 60 and 72 months $(N=69)$, while the remainder were 48 - 60 months $(\mathrm{N}=48)$ and 36 - 48 months $(\mathrm{N}=19)$, respectively.

\section{Data Collection Instruments:}

\section{- Personal Information Form:}

The three-part form was created by the researcher herself for the purposes of the research in question. In the first part of the form, information about the researcher is given, while the second part includes information about the child's gender, age, birth order, family structure, number of siblings, and the togetherness of the parents. In the third part of the Personal Information Form, questions ask about the parents' gender, age, educational status, profession, family structure, monthly income, number of siblings, daily working hours, time spent daily with their children, social media usage outside work, the geographical region based on family origins and information on the child-rearing attitude adopted by the family. The Personal Information Form is included in Appendix A.

\section{- Parents' Gendered Emotion Beliefs Scale:}

The Parents' Gendered Emotion Beliefs (PGEB) scale was developed and validated by Thomassin et al. (2019) to measure parents' gendered beliefs based on a scale in which parents give information about themselves. PGEB was validated in a sample of 704 parents, comprised of 349 mothers and 355 fathers with children aged 8-12 living in Canada and the USA. Factor analysis revealed a structure consisting of 
three sub-factors with five items: gendered expression, gender-neutral expression, and gendered socialization.

The scale is a 4-point Likert scale $(1=$ strongly disagree, $2=$ disagree, $3=$ agree, $4=$ strongly agree $)$ and consists of 15 items. Cronbach's alpha reliability coefficients were found to be $\alpha=0.800$ for mothers and $\alpha=0.79$ for fathers in "gender expression", $\alpha=0.790$ for mothers and $\alpha=0.780$ for fathers in "genderneutral expression", and $\alpha=0.900$ for mothers and $\alpha=0.870$ for fathers in "gendered socialization". According to the sub-dimensions, the correlations between the items were found to be $\mathrm{r}=0.44$ for mothers and fathers in "gender expression", $r=0.44$ for mothers and $r=0.30$ for fathers in "gender-neutral expression", and $\mathrm{r}=0.65$ for mothers and $\mathrm{r}=0.58$ for fathers in "gendered socialization". As a result of the analyses, all three sub-factors with five items were compatible when mothers and fathers were compared, and it was concluded that the entire scale could be used for both mothers and fathers (Thomassin et al., 2019).

The PGEB form can be administered and scored in 5 minutes in a friendly atmosphere. In this study, the PGEB form was used by adapting it to Turkish (Appendix B).

\section{Data Collection}

1. Language and Content Validity: The necessary correspondence was made with the researcher who originally developed the Parents' Gendered Emotional Beliefs Scale (PGEB) and permission was obtained to adapt the scale into Turkish and apply it to parents of children aged 36-72 months. At the beginning of the process, three English language experts and the researcher translated the scale from English to Turkish to obtain semantic equivalence. The items translated into Turkish were edited by the field expert, and a reverse translation of the scale items from Turkish to English was carried out by a linguist after the necessary corrections.

The suitability of the expressions in the scale Turkish culture and their ability to measure the qualities desired to be measured were examined by taking the opinions of seven experts working in the fields of Child Development and Preschool Education who had a minimum of a doctorate degree. The experts were asked to evaluate each of the items in the scale with the words "Appropriate/Not Appropriate" in terms of compliance with the target, and to make comments that would enable the scale items to be improved. As a result of the opinions of the seven field experts, it was determined that corrections were not necessary and the final version of the scale was sent to seven kindergarten teachers to gather their opinions.

Finally, seven teachers were asked to evaluate the items in the scale with the words "Appropriate/Not Appropriate" in terms of the clarity and comprehensibility of the research. Considering the opinions received from seven teachers, it was seen that the teachers considered all of the items to be "Appropriate".

2. Implementation Phase: Within the scope of the validity and reliability analyses of the scale, a pilot practise was conducted to determine the level of comprehensibility of the statements and any problems that could occur by applying the scales to 5 mothers and 5 fathers residing in the Bahçelievler district of Istanbul with children in the 3-6 year old age group who were chosen randomly.

As a result of the pilot practise, the duration required to administer the scale was found to be 4 minutes on average. There were no problems with the comprehensibility of the scale and the application environment.

\section{Ethical Side of Research}

Approval to conduct the study was obtained from the Fatih Sultan Mehmet Vakif University Ethics Committee and parents with 36-72 months old children studying in pre-school education institutions in the Bahçelievler district of Istanbul were contacted. The Fatih Sultan Mehmet Vakif University Ethics Committee approval document is attached (Appendix C). 


\section{Data Collection:}

The data were collected in a playground in the Bahçelievler district of Istanbul, which is frequently visited by children between the ages of 3-6 and their parents. The parents were informed that participation was voluntary, their answers would remain confidential, the purpose and content of the study, and were asked to mark the most appropriate option for each item in the scaleby giving realistic answers. It was stated that items should not be left unanswered. Parents who volunteered to participate in the study filled in the scale and handed it over to the researcher.

\section{RESULTS}

\section{Exploratory Factor Analysis:}

The scale was analyzed by Exploratory Factor Analysis (EFA). Exploratory Factor Analysis is a variable reduction technique that aims to reach a small number of variables (factors) from a large number of observable variables (items) created to measure a certain structure (Büyüköztürk, 2006). Detailed information on the load value of the items as a result of EFA can be found in Table 1.

Table 1. Explanatory factor analysis results

\begin{tabular}{lccc}
\hline \multicolumn{1}{c}{ Items } & $\begin{array}{c}\text { FI (Gender-Neutral } \\
\text { Expression }\end{array}$ & $\begin{array}{c}\text { FII (Gender } \\
\text { Expression) }\end{array}$ & $\begin{array}{c}\text { FIII (Gendered } \\
\text { Socialization) }\end{array}$ \\
\hline $1^{\text {st Item }}$ & 0.08 & $\mathbf{0 . 7 8}$ & 0.25 \\
$2^{\text {nd }}$ Item & $\mathbf{0 . 5 6}$ & 0.01 & 0.06 \\
$3^{\text {rd }}$ Item & 0.13 & $\mathbf{0 . 8 0}$ & 0.22 \\
$4^{\text {th }}$ Item & 0.10 & 0.17 & $\mathbf{0 . 6 5}$ \\
$5^{\text {th }}$ Item & 0.39 & $\mathbf{0 . 6 8}$ & 0.09 \\
$6^{\text {th }}$ Item & 0.18 & 0.16 & $\mathbf{0 . 8 6}$ \\
$7^{\text {th }}$ Item & 0.25 & 0.27 & $\mathbf{0 . 8 6}$ \\
$8^{\text {th }}$ Item & $\mathbf{0 . 7 5}$ & 0.37 & 0.09 \\
$9^{\text {th }}$ Item & 0.13 & $\mathbf{0 . 7 9}$ & 0.16 \\
$1^{\text {th }}$ Item & 0.20 & 0.14 & $\mathbf{0 . 8 3}$ \\
$1^{\text {th }}$ Item & 0.16 & $\mathbf{0 . 6 6}$ & 0.15 \\
$1^{\text {th }}$ Item & $\mathbf{0 . 6 1}$ & 0.32 & 0.27 \\
$1^{\text {th }}$ Item & 0.24 & 0.20 & $\mathbf{0 . 8 4}$ \\
$1^{\text {th }}$ Item & $\mathbf{0 . 7 8}$ & 0.24 & 0.19 \\
$1^{\text {th }}$ Item & $\mathbf{0 . 6 9}$ & 0.02 & 0.27 \\
\hline
\end{tabular}

\section{Reliability Analysis:}

Within the scope of the reliability analysis of the scale, Cronbach's alpha analysis was performed to evaluate the reliability of the sub-factors of Gender-Neutral Expression (FI), Gender Expression (FII), and Socialization by Gender (FIII). Cronbach's alpha shows that the only measurement made does not contradict itself without the need for more measurements (Can, 2018). As a result of the analysis of factor I, the reliability coefficient of 5 items was found to be $\alpha=0.71$. As a result of the analysis of Factor II, the reliability coefficient of 5 items was found to be $\alpha=0.80$, while the reliability coefficient of 5 items belonging to Factor III was $\alpha=$ 0.87 . The general scale consisting of 15 items belonging to three factors has a reliability coefficient of $\alpha=0.75$. 
It is generally accepted that the alpha coefficient in the range of " $0.60-0.80$ " is very reliable and a coefficient in the range "0.80-1.00" is highly reliable. According to these results, it can be said that the internal consistency of all sub-factors and the general scale is in a very reliable and acceptable range (Tavşancıl, 2006).

\section{Factor Analysis:}

Before the factor analysis of the scale was conducted, Kaiser-Meyer-Olkin (KMO) and Bartlett tests were applied. The KMO test value indicates the acceptability for factor analysis. If the KMO value is between 0.5 1.00 , it is considered acceptable, while values of 0.8 and above indicate a high fit and 1 indicates a perfect fit (Altunışık et al., 2012; Büyüköztürk, 2006). In this study, the sample fit was found to be significant $(\chi 2(105)=$ $790, \mathrm{p}<0.001)$ and strong $(\mathrm{KMO}=0.80)$. According to the relevant results, it was determined that it was acceptable for factor analysis on the scale.

In order to determine the construct validity of the scale after the application, factor analysis of the data obtained according to the answers received from 136 parents was performed. During the factor analysis, principal component analysis and the transformation between factors were calculated by Kaizer normalization and promax $(=4)$. When the scree plot (Figure 1) was examined, it was determined that the elbow point came out after the 3rd factor and a 3-factor analysis was performed by cutting from this point.

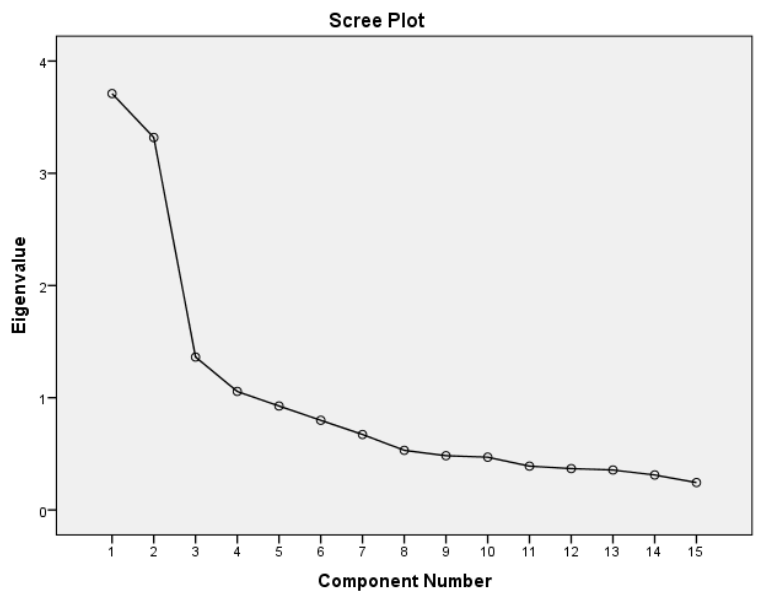

Fig.1: Scree plot resulting from the ordinal exploratory factor analysis.

The analysis results indicated the existence of a three-factor structure that is meaningful and can be named, and this factorial structure was later confirmed by confirmatory factor analysis. It was determined that the three factors obtained as a result of the analysis explained $57.82 \%$ of the variance with a total eigenvalue of 8.66. The first factor, called "Gender-Neutral Expression", accounts for 9.83\% of the variance; the second factor called "Gender Expression" explains $21.56 \%$ of the variance and the third factor called "Gendered Socialization" explains $26.43 \%$ of the variance.

When the correlations between the factors were examined, it was determined that FI and FIII $(r=0.26)$, as well as FIII and FII $(r=0.21)$ showed a weak positive correlation, while FI and FII $(r=-0.24)$ showed a weak negative correlation.

\section{Confirmatory Factor Analysis:}

Confirmatory Factor Analysis was used to examine the extent to which the three-factor structure of the scale was compatible with the data collected. Confirmatory Factor Analysis (CFA) is a natural extension of Explanatory Factor Analysis (EFA). The purpose of confirmatory factor analysis is to statistically check the meaningfulness of a structure (model) consisting of a known number of factors. In other words, CFA is used to test whether the sample data confirms the proposed structure (Y1lmaz et al., 2009). In CFA, it is determined 
whether the model is compatible with the theory, not according to the result of a single test, but according to the results of various fit indexes (Çapık, 2014).

Among the fit indices based on the independent model, CFI (Comparative Fit Index) is the most frequently used. It compares the fit of the current model with the fit of the null hypothesis model, which the absence of correlation and covariance between latent variables. Therefore, it compares the covariance matrix estimated by the model with the covariance matrix of the model with the null hypothesis. The CFI, which has values ranging from 0 to 1 , indicates that the closer the value to 1 , the better the fit, and it emphasizes that the model with a higher CFI is in a stronger fit in parallel. The Tucker-Lewis Index (TLI) was developed to resolve the deficiency of the Normed Fit Index (NFI) being affected by sample size. The larger the TLI value, the higher the goodness of fit for the model. Values greater than 0.95 are interpreted as showing an acceptable fit (Cangur \& Ercan, 2015). As a result of the confirmatory factor analysis, the model was found to have factorial validity $(2(87)=115.83, \mathrm{p}<0.05)$. When the other accuracy (fit index) values were examined, it was found that the values were acceptable. The comparative fit index (CFI) value is 0.96 , and the Tucker - Lewis Index (TLI) value is 0.95 .

When the correlations of the factors were examined, it was found that the pattern in fit index values was repeated with a higher emphasis (see Table 2).

Table 2: Correlations of Factors

\begin{tabular}{|c|c|c|c|c|c|c|c|}
\hline & & \multirow[b]{2}{*}{ Measurement } & \multirow[b]{2}{*}{$\begin{array}{l}\text { Standard } \\
\text { error }\end{array}$} & \multirow[b]{2}{*}{$\begin{array}{l}\text { Z- } \\
\text { value }\end{array}$} & \multirow[b]{2}{*}{$\mathbf{P}$} & \multicolumn{2}{|c|}{$\begin{array}{l}\text { 95\% Confidence } \\
\text { Interval }\end{array}$} \\
\hline & & & & & & Low & High \\
\hline $\begin{array}{l}\text { Factor } \\
1\end{array}$ & $\uplus_{2}^{\text {Factor }}$ & -0.33 & 0.10 & -3.26 & $1.11 \mathrm{e}-3$ & -0.52 & -0.13 \\
\hline $\begin{array}{l}\text { Factor } \\
1\end{array}$ & $\Theta_{3}^{\text {Factor }}$ & 0.29 & 0.10 & 2.92 & $3.46 e-3$ & 0.09 & 0.48 \\
\hline $\begin{array}{l}\text { Factor } \\
2\end{array}$ & $\Theta_{3}^{\text {Factor }}$ & 0.31 & 0.09 & 3.31 & $<.001$ & 0.12 & 0.49 \\
\hline
\end{tabular}

It was found that the factor and item loadings found in the explanatory factor analysis (Table 2) were also observed in the confirmatory factor analysis (see Table 3, Figure 2). 
Table 3: Factor and Element Structure

\begin{tabular}{|c|c|c|c|c|c|c|c|c|}
\hline \multirow[b]{2}{*}{ Factor } & \multirow[b]{2}{*}{ Indicator } & \multirow[b]{2}{*}{ Symbol } & \multirow[b]{2}{*}{ Measurement } & \multirow[b]{2}{*}{$\begin{array}{l}\text { Standard } \\
\text { error }\end{array}$} & \multirow[b]{2}{*}{$\begin{array}{l}\text { z- } \\
\text { value }\end{array}$} & \multirow[b]{2}{*}{ p } & \multicolumn{2}{|c|}{$\begin{array}{c}95 \% \\
\text { Confidence } \\
\text { Interval } \\
\end{array}$} \\
\hline & & & & & & & Low & High \\
\hline \multirow[t]{5}{*}{ Factor 1} & VAR2 & $\lambda 11$ & 0.29 & 0.08 & 33.67 & $<.001$ & 0.14 & 0.45 \\
\hline & VAR8 & $\lambda 12$ & 0.47 & 0.06 & 6.58 & $<.001$ & 0.35 & 0.59 \\
\hline & VAR15 & $\lambda 13$ & 0.40 & 0.07 & 75.98 & $<.001$ & 0.27 & 0.54 \\
\hline & VAR4 & $\lambda 14$ & 0.47 & 0.06 & 8.39 & $<.001$ & 0.36 & 0.58 \\
\hline & VAR12 & $\lambda 15$ & 0.38 & 0.06 & 6.71 & $<.001$ & 0.27 & 0.50 \\
\hline \multirow[t]{5}{*}{ Factor 2} & VAR1 & $\lambda 21$ & 0.64 & 0.07 & 8.90 & $<.001$ & 0.50 & 0.79 \\
\hline & VAR3 & $\lambda 22$ & 0.65 & 0.07 & 79.47 & $<.001$ & 0.52 & 0.79 \\
\hline & VAR11 & $\lambda 23$ & 0.45 & 0.07 & 76.54 & $<.001$ & 0.32 & 0.59 \\
\hline & VAR5 & $\lambda 24$ & 0.42 & 0.06 & 6.93 & $<.001$ & 0.30 & 0.54 \\
\hline & VAR9 & $\lambda 25$ & 0.62 & 0.07 & 78.84 & $<.001$ & 0.48 & 0.76 \\
\hline \multirow[t]{5}{*}{ Factor 3} & VAR4 & $\lambda 31$ & 0.49 & 0.07 & 76.69 & $<.001$ & 0.34 & 0.63 \\
\hline & VAR6 & $\lambda 32$ & 0.66 & 0.06 & 511.14 & $<.001$ & 0.54 & 0.78 \\
\hline & VAR13 & $\lambda 33$ & 0.61 & 0.06 & 510.95 & $<.001$ & 0.50 & 0.72 \\
\hline & VAR7 & $\lambda 34$ & 0.67 & 0.06 & 12.11 & $<.001$ & 0.56 & 0.78 \\
\hline & VAR10 & $\lambda 35$ & 0.60 & 0.06 & 10.26 & $<.001$ & 0.49 & 0.72 \\
\hline
\end{tabular}

Factor - Item interaction graph (see Fig. 2 is as follows):

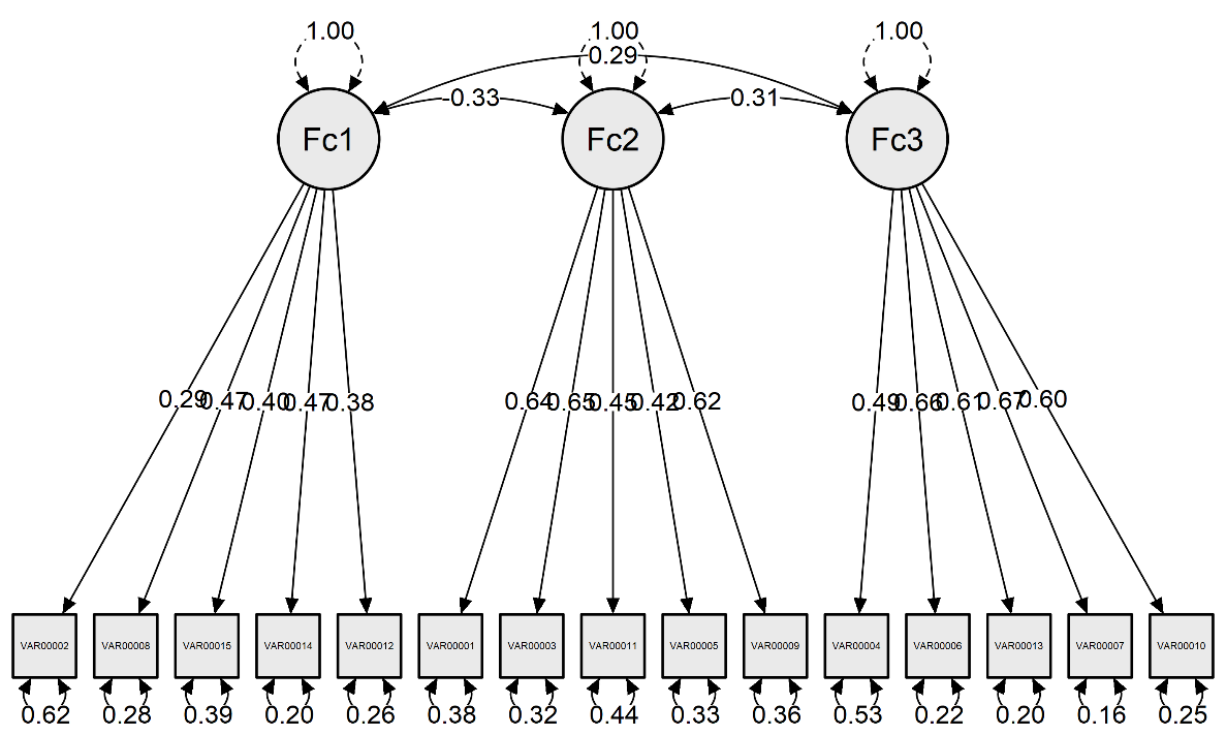

Figure 2: Factor - Item Interaction Graph

\section{Independent Samples T-Test:}

Analyses on the original scale showed that it can be used for both mothers and fathers. The independent samples t-test was conducted to determine whether there was a statisticial significant difference between the responses of mothers and fathers in terms of "Gender-Neutral Expression", "Gender Expression" and "Gendered Socialization". 
No significant difference was found between the scores of mothers (Avg $=3.30, \mathrm{SD}=.46)$ and fathers (Avg $=3.19, \mathrm{SD}=.54)$ in terms of gender-neutral expression $(\mathrm{t}=1.12, \mathrm{p}>.05)$.

No significant difference was found between the scores of the mothers (Avg $=2.02, \mathrm{SD}=.64)$ and fathers $($ Avg $=2.12, \mathrm{SD}=.60)$ in terms of gender expression $(t=-.96, p>.05)$.

No significant difference was found between the scores of mothers (Avg $=2.91, \mathrm{SD}=.68)$ and fathers (Avg $=2.78, \mathrm{SD}=.63)$ in terms of gendered socialization $(\mathrm{t}=1.14, \mathrm{p}>.05)$.

In order to make meaningful comparisons between the mother and father groups, results consistent with the original scale were obtained based on the analyses made by taking into account the required measurement invariance.

\section{CONCLUSION and DISCUSSION}

The preschool period is a particularly important developmental period in terms of examining gender and emotional socialization. In this period, the child learns about social figures, social relations and social roles much faster with the advantages of developmental characteristics. As they being to gain the roles attributed by gender in this period, they can express the behaviors expected from their gender by comparing with their own gender and the opposite sex (Seven, 2018). For example, in a study conducted by Brechet with female and male pre-school students in France in 2013, gender stereotypes that students attribute to emotions were investigated. The students were read two stories in which the feelings of anger and sadness were dominant, using both genders, and then the students were asked to draw how the hero in this story felt. While the feeling of anger was better expressed by male and female students in the story with the male protagonist, the feeling of sadness could not be expressed, but the feeling of sadness was better expressed in the story with the female protagonist, and the feeling of anger could not be expressed (Brechet, 2013). According to the results of a master's thesis research conducted by Özdemir in 2006 with 120 children attending preschool institutions in Ankara, children between the ages of 5-6 have gender stereotypes and these stereotypes increase with age (Özdemir, 2006). The emotional reactions of parents are a fruitful reference for young children to express their emotions. Children can learn and interpret emotions in this way (Dix, 1991; Nelson et al., 2012; Patterson, 1980). By seeing and hearing emotional expressions within the family, the child also has the opportunity to evaluate other people's emotional experiences. Therefore, they observe their parents' emotional expressions and internalize the information gained from their observations (Root and Denham, 2010). In a study, adult women stated that when they expressed sadness as children, they were supported and interested by their parents, while adult men stated that their families were punished when they expressed these feelings (Çorapç1, 2012). According to the study of Chaplin et al. (2005), parents may ignore emotions depending on the gender of their children. The results of Morojele's research in 2011 are that parents expect boys to not cry and be tough all the time, seek their rights and never show their emotions. Similar results emerged in Dunn, Kopp, and Brown's studies on emotional socialization of families. According to this research, while girls are taught to solve their problems by talking more, boys are expected to be tougher. In the literature, it is stated that from preschool to middle-school age, children benefit from examining emotional expressions in the family, observing parental responses to their emotions and having emotion-based conversations with their parents (Chan, 2012; Wong et al., 2008).

The acceptability of the Parents' Gendered Emotional Beliefs Scale for Turkish families was tested with validity and reliability analyses and it was subsequently adapted to Turkish. Considering the CFA results, the three-factor structure of the original scale was confirmed in this study as well. Three factors of the scale show good internal consistency and validity. The findings obtained as a result of the reliability analysis are sufficient and within acceptable limits. This indicates that the internal consistency of all sub-factors and the overall scale in the Turkish version of the scale is within a very reliable and acceptable range, and that it is a robust and reliable scale for measuring parents' emotional beliefs based on gender.

From an emotional socialization perspective, parents who support gendered beliefs about emotions likely have strict rules about emotional socialization practices and expressions of emotion within the family, such as that boys should not be emotional and girls should not be aggressive. The relationships between parents' beliefs and parenting practices highlight the potential of the scale for use in measuring the factors underlying parenting decisions and explaining the complex findings in the emotional socialization literature. 
No significant difference was found between mothers and fathers in all three factors. Considering the studies in the literature, it is seen that mothers and fathers differ in gendered socialization practices. In studies comparing mothers and fathers within the context of emotional socialization, it was found that fathers did not consider emotional socialization practices as a fatherhood task (Denham \& Kochanoff, 2002). Mothers talk more often about emotions and care more about emotions (Fivush et al., 2000). On the other hand, fathers generally encourage less emotional expression (Fuchs \& Thelen, 1988; Saarni et al., 1998; Zeman \& Garber, 1996) and accept less open expression of negative emotions (Denham \& Kochanoff, 2002). This can be explained by the recent shifts in gender stereotypes between men and women. In addition, it was observed in previous studies that mothers and fathers gave common responses in their children's emotional expressions based on their gender. For example, it was observed that mothers and fathers used more emotional words when discussing sad events with their daughters than with their sons (Fivush et al., 2000). Harmony between spouses can also be seen as a factor that produces this result. Considering the sample of this study, it was observed that 131 parents lived together and 5 parents lived separately. Bonney, Kelley, and Levant (1999) emphasized that marital satisfaction is one of the important factors in the father's participation in the child's care. Supporting these results, Wong, McElwain, and Halberstadt (2009) stated that fathers respond negatively to their child's negative emotions in situations such as conflict and ambivalence in marriage.

The study was conducted with parents of children aged 36-72 months. This is because the preschool period is critical for both emotional and sexual role development. When the studies are examined, it is clear that parents' emotion socialization practices and emotional and social competence are interrelated. It is stated that while the emotional and behavioral development of the child interacts positively with supportive emotional socialization approaches, non-supportive emotional socialization approaches affect social and emotional development negatively (Eisenberg et al., 1998). Emotional competence has long-term repercussions on social competence in early and later ages. It is seen that the skills of understanding and regulating emotions contribute to many social areas, including children's adaptation to school (Shields et al., 2001). Denham and Kochanoff (2002) stated that emotional competence in 3- and 4-year-old children affects their social competencies in the same age period and kindergarten time. Yağmurlu and Altan (2010), in their study involving 145 mothers of children aged 4-5 years, stated that mothers' positive emotional socialization approaches had significant effects on the child's emotion regulation skills. Until their school years, children mostly acquire the ability to communicate and regulate their emotions (Denham, 1998). For these reasons, supportive emotional socialization practices of parents are important in terms of facilitating the adaptation of their children to their social environment, affecting their academic success positively, and predicting their social competencies in later life (Denham et al., 2007).

In addition to biological factors, the effect of cognitive factors is also very important in the development of gender roles. In the process of gender role development, children perform gender coding at different levels as a result of their own gender schemes, expectations of the society, and modeling of other individuals of their gender (Bussey \& Bandura, 1999). In socio-cultural terms, using adjectives such as "ladylike" for girls and "lion" for boys, gendered linguistic attributes and labeling affect the development of gender roles in children's self-assessment. These effects have a major role in early gender stereotypes (Butler, 2006; Liben, 2004). Parents' gendered perceptions, from the colors of nursery they prepare for their children to the clothes and toys, reflect the gender roles and expectations of parents in their childhood. Throughout life, gender role and responsibility attributions on biological sex continue with the social environment (Connell, 1996; Davis, 2007). Kohlberg stated that at the last stage of gender development, where the effort to adapt to gender stereotypes suitable for cultural influences is observed, the acquisition of gender continuity is formed (Cyphers et al., 2007). Parents, on the other hand, are an important factor in this process with the reinforcements they give to behaviors in accordance with gender stereotypes. In particular, infancy and early childhood should be addressed in studies examining the factors affecting the development of gender role (Kale \& Özgün, 2016).

In addition, Stevens et al.(2002) studied single mothers in their research, and found no evidence showing a difference in the sexual identity behaviors of children who grew up without a father in the preschool period from other children. As a result of the research, it was concluded that the sexual role development of preschool children continued even in the absence of the father figure. This situation can be explained by the fact that parents are not the only factor affecting the individual's gender role development and sexual identity acquisition. 
The present findings should be interpreted taking into account the limitations of the research. Future research would benefit from further validation of the Parents' Gendered Emotional Beliefs Scale in social examples. The study was conducted on a total of 136 parents (69 mothers and 67 fathers) living in Bahçelievler, Istanbul who had pre-school children aged 36-72 months. Future studies with larger samples will contribute to the literature. The fact that this study, which aims to examine the psychometric properties of parents' gendered emotion beliefs, was carried out only with parents living in the Bahçelievler district of Istanbul can also be seen as a limitation of the study. Our sample in this study was relatively homogeneous in terms of ethnicity and socioeconomic status. Future research will benefit from testing the scale on more heterogeneous samples. The measured gendered emotional beliefs are restricted to the parents of preschool children. The current validity of the Turkish version of the scale is a key that opens the door to examining more subtle developmental and contextual factors in child development. In order to further validate the usefulness of current research that examines the important relationships of gender-related beliefs and emotional socialization, it would be useful to examine the relationship between parents' expressed beliefs and their parenting practices by observing them at home or in a laboratory setting. It will be useful to examine the twoway connections between parents' expectations about their child's gender and the interactions of the child's behavior, as in the study of Lollis and Kuczynski (1997), which investigated the dynamics between interactions and relationships. Future longitudinal studies will be able to detect any causal link.

The Turkish form of the "Parents' Gendered Emotion Beliefs Scale" developed by Thomassin et al. (2019), whose validity and reliability study was conducted for parents with children in pre-school period of 36-72 months and adapted to examine the gendered emotion beliefs of parents, is very useful. The Turkish version of the scale is administered by scoring the items and can be applied immediately without taking the parents' time. The highest score that can be obtained from the adapted scale is 60 and the lowest score is 15 . The scale is valid for all parents and can be used regardless of any special circumstances. Therefore, it can be said that the Turkish version of the scale can be used by researchers in studies conducted in Turkish culture to measure parents' emotional beliefs based on gender. It is very important for researchers who want to examine parents' gendered emotion beliefs and the effects of these beliefs to have a safe measurement tool that they can use.

Understanding parents' beliefs about gender and emotion is important, not only to better understand parenting behavior, but also to convey beliefs to children more directly (Harkness \& Super 2002). Having a measuring tool will help us understand the role of gender in the emotional socialization and emotional development of children. It is predicted that the Turkish version of the scale in question will help research on the effects of parents' emotional socialization behaviors on children, which can be considered a new topic in Turkish literature, and will provide significant benefits to parenting and emotional socialization.

\section{RECOMMENDATIONS}

The Turkish form of the "Parents' Gendered Emotion Beliefs Scale" is appropriate in clinical and developmental research, educational research, and studies investigating family systems that address the areas of gender, social-emotional development and well-being of children. By developing this scale, it can be used to measure beliefs in other individuals such as teachers and peers. The scale adapted for parents of children aged 36-72 months in this study can be adapted for different age groups in future studies. In the current study, only the parents of children with normal development were studied. In future studies, it is recommended that the parents of children diagnosed with special education are included.

In order to make correct emotional socialization practices and to understand the emotional development of children, it is recommended that educators should be given in-service training and the importance of the concept of emotional socialization in emotional development should be included in teacher training education policies. As a result, it will be possible for educators to inform and support parents about the effect of correct emotional socialization practices. Preschool teachers can be trained on the use of the Parents' Gendered Emotion Beliefs Scale so that they can evaluate the effect of gendered emotion socialization practices and parents' emotion socialization practices, and create the necessary training program and materials. 


\section{REFERENCES}

Adams, G., \& Anderson, S. L., ve Adonu, J. K. (2004). The cultural grounding of closeness and intimacy.In D. Mashek ve A. Aron (Eds.), Handbook of closeness and intimacy (pp. 321-339). Mahwah, NJ: Lawrence Erlbaum Associates.

Adams, S., Kuebli, J., Boyle, P.A., \& Fivush, R. (1995). Gender differences in parent-child conversations about past emotions: A longitudinal investigation. Sex Roles, 33, 309-323.

Altunışık, R., Coşkun, R., Bayraktaroğlu, S. \& Yıldırım, E. (2012). Sosyal bilimlerde araştirma yöntemleri (7. bs.), Sakarya: Sakarya Yayıncllik.

Block, J. H. (1983). Differential premises arising from differential socialization of the sexes: some conjectures. Child Development, 54, 1335-1354.

Bonney, J. F., Kelley, M. L., \& Levant, R. F. (1999). A model of fathers' behavioral involvement in child care in dual-earner families. Journal of Family Psychology, 13(3), 401-415.

Brody, L. R. (1997). Gender and emotion: Beyond stereotypes. Journal of Social Issues, 53(2), 369-393.

Brody, L. R. (2000). The socialization of gender differences in emotional expression: Display rules, infant temperament, and differentiation. In: A. H. Fischer (Ed.), Studies in emotion and social interaction. Second series. Gender and emotion: Social psychological perspectives (p. 24-47). Cambridge University Press.

Bussey, K., \& Bandura, A. (1999). Social cognitive theory of gender development and differentiation. Psychological Review, 106(4), 676-713.

Butler, J. (2006). Gender trouble. New York: Routledge Press.

Büyüköztürk, Ş. (2006). Sosyal bilimler için veri analizi el kitabı. Ankara: Pegem A Yayıncılık.

Can, A. (2018). SPSS ile bilimsel araştirma sürecinde nicel veri analizi (6. bs.). Ankara: Pegem Akademi.

Cangur, Ş., \& Ercan, İ. (2015). Comparison of model fit indices used in structural equation modeling under multivariate normality. Journal of Modern Applied Statistical Methods, 14(1), 152-167.

Çapık, C. (2014). Geçerlik ve güvenirlik çalişmalarinda doğrulayici faktör analizinin kullanimi. Anadolu Hemşirelik ve Sağlık Bilimleri Dergisi, 17(3), 196-205.

Cassano, M., Parrish, Carisa., \& Zeman, J. (2007). Influence of gender on parental socialization of children's sadness regulation. Social Development, 16(2), 210-231.

Chan, S. (2012). Links between Chinese mothers' parental beliefs and responses to children's expression of negative emotions. Early Child Development and Care, 182, 723-739.

Chaplin, T. M. \& Aldao, A. (2013). Gender differences in emotion expression in children: a meta-analytic review. Psychological Bulletin, 139(4), 735-765.

Chaplin, T. M., Cole, P. M., \& Zahn-Waxler, C. (2005). Parental socialization of emotion expression: gender differences and relations to child adjustment. Emotion, 5(1), 80-88.

Connell, R. W. (1996). Teaching the boys: New research on masculinity, and gender strategies for schools. Teachers College Record, 98(2), 206-235.

Crick, N. R. (1997). Engagement in gender normative versus nonnormative forms of aggression: Links to socialpsychological adjustment. Developmental Psychology, 33(4), 610-617.

Davis, S. N. (2007). Gender ideology construction from adolescence to young adulthood. Social Science Research, 36(3), 1021-1041.

Denham, S. A. (1998). Emotional development in young children. New York: Guilford Press.

Denham, S. A., Bassett, H. H., \& Wyatt, T. M. (2007). The socialization of emotional competence. In: J. Grusec \& P. Hastings (Eds), Handbook of socialization: theory and research. New York, NY: Guilford Press.

Denham, S. A., Mitchell-Copeland, J., Strandberg, K., Auerbach, S., \& Blair, K. (1997). Parental contributions to preschoolers' emotional competence: Direct and indirect effects. Motivation and Emotion, 21(1), 65-86.

Denham, S., \& Kochanoff, A. T. (2002). Parental contributions to preschoolers' understanding of emotion. Marriage \& Family Review, 34(3-4), 311-343. 
Dix T. (1991). The affective organization of parenting: adaptive and maladaptive processes. Psychological bulletin, 110(1), 3-25.

Eisenberg, N., Cumberland, A., \& Spinrad, T. L. (1998). Parental socialization of emotion. Psychological Inquiry, 9(4), 241-273.

Fivush, R. (1989). Exploring sex differences in the emotional content of mother-child conversations about the past. Sex Roles: A Journal of Research, 20(11-12), 675-691.

Fivush, R. (1991). Gender and emotion in mother-child conversations about the past. Journal of Narrative $\mathcal{E}$ Life History, 1(4), 325-341.

Fivush, R., \& Wang, Q. (2005). Emotion talk in mother-child conversations of the shared past: the effects of culture, gender, and event valence. Journal of Cognition and Development, 6(4), 489-506.

Fivush, R., Brotman, M., Buckner, J.P., \& Goodman, S. (2000). Gender differences in parent-child emotion narratives. Sex Roles, 42(3), 233-253.

Fuchs, D., \& Thelen, M. (1988). Children's expected interpersonal consequences of communicating their affective state and reported likelihood of expression. Child Development, 59(5), 1314-1322.

Garner, P. W., Robertson, S., \& Smith, G. (1997). Preschool children's emotional expressions with peers: The roles of gender and emotion socialization. Sex Roles, 36, 675-691.

Jansz, J. (2000). Masculine identity and restrictive emotionality. In: A. H. Fischer (Ed.), Gender and Emotion: Social Psychological Perspectives (pp. 166-188). Cambridge: Cambridge University Press.

Kale, M., \& Özgün, Ö. (2016). Cinsiyet rolü gelişimi ve bu gelişimi etkileyen faktörler. İçinde: S. Y. Güder (Editör), Erken Çocuklukta Cinsel Eğitim ve Toplumsal Cinsiyet (s. 79-97). Ankara: Eğiten Kitap.

Klimes-Dougan, B., Brand, A. E., Zahn-Waxler, C., Usher, B., Hastings, P. D., Kendziora, K., \& Garside, R. B. (2007). Parental emotion socialization in adolescence: Differences in sex, age and problem status. Social Development, 16(2), 326-342.

Kuebli, J., \& Fivush, R. (1992). Gender differences in parent-child conversations about past emotions. Sex Roles: A Journal of Research, 27(11-12), 683-698.

Liben, L. (2004). Cultural development and gender development: Shared concepts, methodologies, and challenges. Human Development, 47(3), 179-184.

Lollis, S., \& Kuczynski, L. (1997). Beyond one hand clapping: Seeing bidirectionality in parent-child relations. Journal of Social and Personal Relationships, 14(4), 441-461.

Lytton, H., \& Romney, D. M. (1991). Parents' differential socialization of boys and girls: A metaanalysis. Psychological Bulletin, 109(2), 267-296.

Nelson, J. A., O'Brien, M., Calkins, S. D., Leerkes, E. M., Marcovitch, S., \& Blankson, A. N. (2012). Maternal expressive style and children's emotional development. Infant and child development, 21(3), 267286.

O'Neal, C. R., \& Magai, C. (2005). Do parents respond in different ways when children feel different emotions? The emotional context of parenting. Development and Psychopathology,17, 467-487.

Root, A.K., \& Denham, S. (2010). The role of gender in the socialization of emotion: key concepts and critical issues. New directions for child and adolescent development, 128, 1-9.

Saarni, C., Mumme, D. L., \& Campos, J. J. (1998). Emotional development: Action, communication, and understanding. In W. Damon \& N. Eisenberg (Ed.), Handbook of child psychology: Social, emotional, and personality development (p. 237-309). John Wiley \& Sons, Inc..

Serbin, L. A., Powlishta, K. K., \& Gulko, J. (1993). Sex roles, status, and the need for social change. Monographs of the Society for Research in Child Development, 58(2), 93-95.

Seven, S. (2018). Çocuk ruh sağhığı. Ankara: Pegem Akademi.

Shields, A., Dickstein, S., Seifer, R., Giusti, L., Magee, K. D., \& Spritz, B. (2001). Emotional competence and early school adjustment: A study of preschoolers at risk. Early Education and Development, 12(1), 7396. 
Stevens, M., Golombok, S., Beveridge, M., \& ALSPAC Study Team, University of Bristol. (2002). Does father absence influence children's gender development?: Findings from a general population study of preschool children. Parenting: Science and Practice, 2(1), 47-60.

Tavşancıl, E. (2006). Tutumların ölçülmesi ve spss ile veri analizi. Ankara: Nobel Yayın Dağıtım.

Tenenbaum, H. R., \& Leaper, C. (2002). Are parents' gender schemas related to their children's gender-related cognitions? A meta-analysis. Developmental Psychology, 38(4), 615-630.

Thomassin, K., Seddon, J. A., \& Vaughn-Coaxum, R. (2019). Development and validation of the parents' gendered emotion beliefs scale. Journal of Child and Family Studies, Advance online publication. https://doi.org/10.1007/s10826-019-01591-6

Wong MS, Diener M. \& Isabella R.A. (2008). Parents' emotion related beliefs and behaviors and child grade: Associations with children's perceptions of peer competence. Journal of Applied Developmental Psychology, 29, 175-186.

Yagmurlu, B. \& Altan, O. (2010). Maternal socialization and child temperament as predictors of emotion regulation in Turkish preschoolers. Infant and Child Development, 19(3), 275-296.

Yılmaz, V., Aktaş, C. \& Arslan, M.S.T., (2009). Müşterilerin kredi kartina olan tutumlarinin çoklu regresyon ve faktör analizi ile incelenmesi. Balıkesir Üniversitesi Sosyal Bilimler Enstitüsü Dergisi, 12(22), 127139.

Zeman, J., \& Garber, J. (1996). Display rules for anger, sadness, and pain:It depends on who is watching. Child Development, 67(3), 957-973.

Zeman, J., Perry-Parrish, C., \& Cassano, M. (2010). Parent-child discussions of anger and sadness: the importance of parent and child gender during middle childhood. New Directions for Child and Adolescent Development, (128), 65-83. 